\title{
TEMPORAL CHANGES OF GLACIER HYDROLOGICAL SYSTEMS INDICATED BY ISOTOPIC AND RELATED OBSERVATIONS AT AUSTRE OKSTINDBREEN, OKSTINDAN, NORWAY, 1976-87
}

by

Wilf red $\mathrm{H}$. Theakstone

(Department of Geography, University of Manchester, Manchester M13 9PL, England, U.K.)

and

N. Tvis Knudsen

(Geological Institute, University of Aarhus, DK-8000 Aarhus C, Denmark)

\section{ABSTRACT}

Twelve years of observation at Austre Okstindbreen, Norway, have demonstrated that the drainage systems of glaciers change with time, both between and within seasons. Random events indicative of instability have been recorded, and disruption of the glacier systems has preceded some outbursts from Kalvtjørna, the glacier-dammed lake. The results of dye-tracer tests suggest that, although discrete systems exist within the glacier, these vary between years. They also demonstrate that some of the water entering the glacier is stored temporarily as the capacities of the systems change. The chemical composition of river water emerging from Austre Okstindbreen differs from year to year, and it is found that both systematic patterns of variation and random deviations from them occur. Although waters of different origin mix within drainage systems, not all systematic patterns of isotopic composition are eliminated by this mixture; diurnal variations are superimposed on longer-term trends, which sheds light on drainage conditions. Between-year differences of within-season trends probably reflect changing spatial patterns of drainage. The general level of oxygen-isotope $\left(\delta^{18} \mathrm{O}\right)$ values of bulk glacier river water in a particular summer is much lower than the values of $\delta^{18} \mathrm{O}$ for old snow and glacier ice, and indicates the relative contribution of the base-flow component, which may be sustained either by accumulation-area sources or by water release from storage.

\section{INTRODUCTION}

In areas where glaciers contribute significantly to water supplies, efficient resource management requires knowledge of the relative importance of the different sources (ice melt, snow melt, rainfall) and of the routes and transit times of water which passes through the glaciers. Much water may be stored within a glacier, particularly at its bed. Although knowledge of the nature of the hydrological systems within and beneath glaciers is needed if glacier movement is to be understood, little is known with certainty at present about either the stability or the efficiency of subglacial water channels (Clarke, 1987). Hydrological observations at the Norwegian glacier Austre Okstindbreen during the last 12 years have demonstrated that glacier-drainage systems change with time, both between and within seasons. Investigation of these changes, and of their effects on water issuing from the glacier, has provided information of general value to glacier hydrological studies.

\section{THE STUDY AREA}

Water from all the glaciers of the Okstindan area of Norway (Fig. 1) is used in hydro-electric power generation. Since 1908, when they were first studied (Hoel, 1910), the glaciers have become much smaller; the largest, Austre Okstindbreen, now covers about $14 \mathrm{~km}^{2}$. In 1908, the lower part of Austre Okstindbreen divided into two branches and rivers issued from both; that from the northern branch flowed to Lake Kjennsvatnet, and that from the eastern branch discharged to Lake Grasvatnet (Fig. 1). In 1976, when a programme of glacier-hydrology investigations was

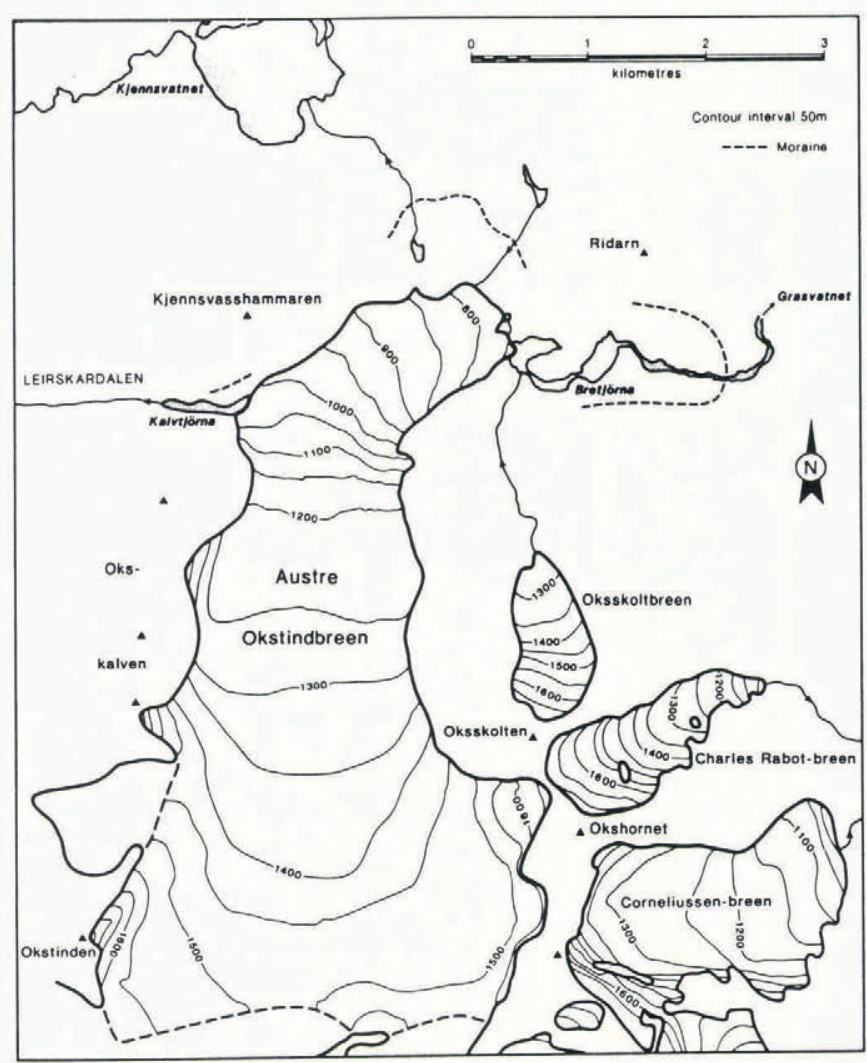

Fig. 1. The glacier Austre Okstindbreen. 
started at Austre Okstindbreen as part of the Okstindan Glacier Project, the glacier's northern branch had almost disappeared, but a river still left the margin at a height of about $845 \mathrm{~m}$ a.s.l. and flowed into Kjennsvatnet. As the surface level continued to be lowered by ablation, the margin retreated across a subglacial threshold and in 1980 the river ceased to issue from the glacier.

\section{WATER DISCHARGE FROM THE GLACIER}

Austre Okstindbreen terminates in a lake at $740 \mathrm{~m}$ a.s.l. Two rivers enter the lake from the glacier, one at its southern border and the other close to its northern side. Generally, the latter accommodates most of the water leaving the glacier throughout the summer. Between 1976 and 1984 it flowed directly into the lake, but in 1985, 1986, and 1987, as the result of glacier retreat, it took a short subaerial course between the glacier margin and the lake. In the summers of 1978 and 1981 the southern river was the major outlet of water from Austre Okstindbreen, and for the first part of the 1985 summer it was larger than the northern river. During a storm on 22 July 1985, however, it ceased to flow and the size of the northern river increased markedly. In 1987, water did not issue from the southern side of the glacier.

Until 1985 the northern river passed through a partly subglacial pond at about $760 \mathrm{~m}$ and had a short subaerial course before flowing back beneath the glacier to reemerge at the lake. For a few days in the middle of July 1985 the surface level of the pond fluctuated, rising sharply as ablation increased in the middle of the day. However, during the 22 July storm the pond drained and the subaerial section of the northern river disappeared. On the following day, the river could be seen taking a new subglacial course flowing down a steep slope close to the glacier margin.

Every summer since 1976 glacier-river levels have been recorded at Austre Okstindbreen. Several random events indicative of instability in the glacier-drainage systems (Ballantyne and McCann, 1980; Burkimsher, 1983) have been recorded. Most frequently these have taken the form of a sudden fall of river level soon followed by an abrupt rise. On several occasions, blocks of ice have been carried from beneath the glacier by the rivers; one such series of events occurred at the southern river on 12 July $1985,10 \mathrm{~d}$ before it ceased to flow.

\section{DRAINAGE OF THE GLACIER-DAMMED LAKE,} KALVTJØRNA

A lake named Kalvtjørna on the map of Okstindan (sheet 2027 III "Storakersvatnet"), published by Statenskartverk in 1986, is shown as being dammed by the western margin of Austre Okstindbreen, at the head of the valley Leirskardalen (Fig. 1). Periodically, this lake drains and water from it then passes through or beneath the glacier instead of flowing down Leirskardalen (Knudsen, 1978; Theakstone, 1978). The drainage events have a marked effect on the subsequent passage of water through the glacier, because drainage of the lake leaves a large conduit within and/or below it. On several occasions, outbursts from the lake have been preceded by disruption of the glacier-drainage systems (Knudsen and Theakstone, 1988). Throughout the summer of 1980 the lake basin remained partly filled, and inflow of water was balanced by outflow into the glacier. A similar situation occurred after the lake outburst of 16 July 1987. For the rest of the summer field season the water level in the basin remained well below the maximum but fluctuated within a range of $\pm 1 \mathrm{~m}$.

\section{DYE-TRACER TESTS FOR WATER MOVEMENT THROUGH THE GLACIER}

Dye tracers have been used to demonstrate that discrete drainage systems exist within the glacier but that these vary from year to year, so that connections which exist during one summer may be absent in another. The tracer tests indicated that whilst some water passes rapidly through
Austre Okstindbreen from points of entry at the surface (Knighton and Theakstone, 1978) throughflow from many other points is characterized by considerable delays. Many tests failed to yield positive results, indicating that the mean velocity at which water passes through the glacier from some points at the surface of the ablation zone is much lower than that of open-channel stream flow. The tracertest data demonstrate that some of the water entering the glacier from crevasses and moulins is stored temporarily, either as a result of changes in the storage capacity within the drainage systems as the glacier moves over an irregular bed, or because water enters subglacial depressions or porous sediments at the bed (Theakstone and Knudsen, 1981). In late July 1979, a major river, its channel almost entirely in the ice and its course approximately parallel with the glacier margin, was found during subglacial explorations down-glacier of the point at which the river flowing to Kjennsvatnet left the glacier. Dye-tracer tests demonstrated that the subglacial river flowed to the $760 \mathrm{~m}$ pond, but that open-channel flow was interrupted (Theakstone and Knudsen, 1981).

\section{WATER CHEMISTRY}

Since 1980, electrical conductivity of glacier-river water has been monitored, and each year samples have been collected for subsequent chemical analysis (Reimann, 1987). In most recent summers an inverse relationship between glacier-river discharge and conductivity has been recorded. Melt water from the surface of the ablation area which passes rapidly through the glacier and has little contact with the bed has low electrical conductivity; it superimposes a diurnal cycle on the solute-rich base-flow component of glacier-river discharge. The chemical composition of river water emerging from Austre Okstindbreen displays both systematic patterns of variation and random deviations from them. These reflect water origin, acquisition of solutes by water discharging, at least in part, over weathered bedrock and sediments at the bed (Raiswell, 1984), and variations in water storage. Marked year-to-year differences in water chemistry have been noted.

In 1981, samples were collected at various times from both rivers discharging from Austre Okstindbreen. Overall, those from the larger southern river had higher $\mathrm{Na}^{+}$ concentrations than had those from the northern river, which were richer in $\mathrm{Ca}^{++}, \mathrm{Mg}^{++}$, and $\mathrm{K}^{+}$(Table I). In 1982 , between $12.00 \mathrm{~h}$ on $15 \mathrm{July}$ and $12.00 \mathrm{~h}$ on $22 \mathrm{July}$, water samples were collected from the northern river where it issued from the glacier into the $740 \mathrm{~m}$ lake; for the rest of the season, until 4 August, they were collected where the river left the $760 \mathrm{~m}$ pond. $\mathrm{Na}^{+}$and $\mathrm{Ca}^{++}$concentrations for the two sets of samples differed; $\mathrm{Na}^{+}$values increased with the change of sampling site but $\mathrm{Ca}^{++}$values decreased (Table I). Subsequent studies have shown that ionic concentrations tend to decrease as the ablation season progresses (Fig. 2). Although no control samples were taken from the lower site during the second part of the 1982 sampling period, the results of the observations as a whole suggest that, as in 1981, there was a significant difference in the quality of the water emerging at the two sampling sites.

In 1983 and 1984, as in 1982, ionic concentrations in the northern glacier river generally were low, with $\mathrm{Na}^{+}$the most abundant of the four elements measured (Table I). Concentrations were highest early in the ablation season and tended to decline with time (Fig. 2). Water-chemistry data from the last part of the 1982 summer field season, from 1983, and from 1984, indicated a general composition of $62: 20: 18$ for $\left(\mathrm{Na}^{+}+\mathrm{K}^{+}\right): \mathrm{Ca}^{++}: \mathrm{Mg}^{++}$.

In general, in $1985, \mathrm{Na}^{+}$concentrations were slightly lower than in previous years but the $\mathrm{Ca}^{++}$and $\mathrm{K}^{+}$values were dramatically higher and $\mathrm{Mg}^{+}$concentrations were also at their highest (Table I). Concentrations of all four cations decreased after the discharge of the northern river had increased substantially and the southern river ceased to flow, on 22 July. In 1986, when sampling was limited, exceptionally high $\mathrm{Ca}^{++}$concentrations were recorded, and $\mathrm{Mg}^{++}$and $\mathrm{K}^{+}$levels were unusually high, in contrast with $\mathrm{Na}^{+}$values which were low. In both 1985 and 1986, the ratio of the ions was of the order of $17: 70: 13$ 
TABLE I. SUMMARY STATISTICS (MAXIMUM, UPPER QUARTILE, MEDIAN, LOWER QUARTILE, MINIMUM) OF COMPOSITION OF WATER SAMPLES COLLECTED AT AUSTRE OKSTINDBREEN $\left(\times 10^{-3} \mathrm{mg} \mathrm{m}^{-3}\right)$; 198IS FROM SOUTHERN GLACIER RIVER; ALL OTHERS FROM NORTHERN RIVER. NUMBER OF SAMPLES $(N)$, SAMPLING PERIOD, INTERVAL $(H)$ INDICATED. SAMPLES COLLECTED BEFORE AND AFTER $18.00 \mathrm{~h}$ ON 22 JULY 1985 LISTED SEPARATELY, IN ADDITION TO BEING GROUPED. INTERRUPTIONS TO SAMPLING OCCURRED IN ALL PERIODS

\begin{tabular}{|c|c|c|c|c|c|c|c|c|c|c|c|}
\hline & $1981 \mathrm{~N}$ & $1981 \mathrm{~S}$ & $1982 \mathrm{~A}$ & 1982B & 1983 & 1984 & 1985 & 1986 & 1987 & $1985 \mathrm{~A}$ & $1985 B$ \\
\hline Period & $4 / 7-2 / 8$ & $9 / 7-3 / 8$ & $15 / 7-22 / 7$ & $22 / 7-4 / 8$ & $1 / 7-12 / 8$ & $6 / 7-6 / 8$ & $6 / 7-31 / 7$ & $11 / 7-17 / 7$ & $12 / 7-29 / 7$ & $6 / 7-22 / 7$ & $22 / 7-31 / 7$ \\
\hline Interval & - & - & 3 & 3 & 3 & 3 & 2 & 2 & 4 & 2 & 2 \\
\hline $\mathrm{Na}^{+} \mathrm{Max}$ & 0.86 & 1.13 & 1.55 & 2.00 & 1.71 & 1.59 & 1.50 & 1.43 & 1.70 & 1.50 & 1.44 \\
\hline $\mathrm{Na}^{+} \mathrm{UQ}$ & 0.35 & 0.83 & 0.83 & 1.61 & 1.34 & 0.79 & 0.60 & 0.79 & 0.72 & 0.63 & 0.49 \\
\hline $\mathrm{Na}^{+}$Med & 0.30 & 0.61 & 0.72 & 1.49 & 1.29 & 0.66 & 0.51 & 0.55 & 0.55 & 0.53 & 0.38 \\
\hline $\mathrm{Na}^{+} \mathrm{LQ}$ & 0.26 & 0.36 & 0.65 & 1.22 & 1.17 & 0.56 & 0.40 & 0.45 & 0.47 & 0.47 & 0.33 \\
\hline $\mathrm{Na}^{+} \mathrm{Min}$ & 0.19 & 0.23 & 0.47 & 0.01 & 0.86 & 0.00 & 0.27 & 0.40 & 0.03 & 0.27 & 0.27 \\
\hline $\mathrm{Na}^{+} N$ & 35 & 36 & 61 & 125 & 92 & 208 & 176 & 47 & 92 & 127 & 49 \\
\hline $\mathrm{K}^{+} \operatorname{Max}$ & 0.59 & 0.67 & 0.31 & 0.32 & 0.56 & 4.50 & 1.81 & 2.63 & 0.75 & 1.81 & 0.98 \\
\hline $\mathrm{K}^{+} \mathrm{UQ}$ & 0.34 & 0.26 & 0.21 & 0.21 & 0.34 & 0.17 & 0.82 & 1.28 & 0.19 & 0.98 & 0.30 \\
\hline $\mathrm{K}^{+}$Med & 0.26 & 0.18 & 0.18 & 0.19 & 0.30 & 0.13 & 0.52 & 0.89 & 0.17 & 0.64 & 0.23 \\
\hline $\mathrm{K}^{+} \mathrm{LQ}$ & 0.24 & 0.12 & 0.14 & 0.16 & 0.28 & 0.11 & 0.29 & 0.80 & 0.12 & 0.38 & 0.18 \\
\hline $\mathrm{K}^{+}$Min & 0.09 & 0.10 & 0.09 & 0.00 & 0.22 & 0.03 & 0.08 & 0.30 & 0.02 & 0.15 & 0.08 \\
\hline $\mathrm{K}^{+} N$ & 35 & 36 & 61 & 122 & 92 & 203 & 176 & 44 & 91 & 127 & 49 \\
\hline $\mathrm{Ca}^{++} \operatorname{Max}$ & 1.16 & 0.52 & 1.22 & 0.93 & 0.56 & 0.74 & 7.38 & 23.00 & 1.60 & 7.38 & 4.41 \\
\hline $\mathrm{Ca}^{++} \mathrm{UQ}$ & 0.99 & 0.29 & 0.68 & 0.39 & 0.39 & 0.23 & 4.37 & 7.07 & 0.75 & 4.86 & 2.07 \\
\hline $\mathrm{Ca}^{++} \mathrm{Med}$ & 0.81 & 0.24 & 0.51 & 0.34 & 0.35 & 0.21 & 3.19 & 3.30 & 0.60 & 3.84 & 1.73 \\
\hline $\mathrm{Ca}^{++} \mathrm{LQ}$ & 0.67 & 0.21 & 0.40 & 0.30 & 0.30 & 0.18 & 1.98 & 2.45 & 0.45 & 2.80 & 1.52 \\
\hline $\mathrm{Ca}^{++}$Min & 0.18 & 0.13 & 0.29 & 0.03 & 0.22 & 0.01 & 0.85 & 1.28 & 0.12 & 1.67 & 0.87 \\
\hline $\mathrm{Ca}^{++} N$ & 35 & 36 & 58 & 111 & 92 & 212 & 175 & 48 & 89 & 127 & 48 \\
\hline $\mathrm{Mg}^{++} \operatorname{Max}$ & 0.24 & 0.23 & 0.34 & 0.34 & 0.77 & 0.97 & 0.89 & 1.45 & 0.74 & 0.89 & 0.35 \\
\hline $\mathrm{Mg}^{++} \mathrm{UQ}$ & 0.18 & 0.15 & 0.21 & 0.26 & 0.28 & 0.10 & 0.42 & 0.73 & 0.21 & 0.44 & 0.21 \\
\hline $\mathrm{Mg}^{++} \mathrm{Med}$ & 0.15 & 0.12 & 0.18 & 0.24 & 0.26 & 0.09 & 0.31 & 0.44 & 0.15 & 0.37 & 0.18 \\
\hline $\mathrm{Mg}^{++} \mathrm{LQ}$ & 0.13 & 0.08 & 0.16 & 0.20 & 0.22 & 0.08 & 0.21 & 0.28 & 0.12 & 0.30 & 0.16 \\
\hline $\mathrm{Mg}^{++} \mathrm{Min}$ & 0.08 & 0.06 & 0.12 & 0.03 & 0.16 & 0.02 & 0.12 & 0.15 & 0.01 & 0.18 & 0.12 \\
\hline $\mathrm{Mg}^{++} N$ & 35 & 36 & 61 & 99 & 92 & 203 & 167 & 42 & 91 & 126 & 51 \\
\hline
\end{tabular}

$\left(\mathrm{Na}^{+}+\mathrm{K}^{+}\right): \mathrm{Ca}^{++}: \mathrm{Mg}^{++} ;$a relatively common composition of glacier melt waters (Raiswell, 1984).

The 1987 cationic concentrations were closer to those of 1982-84 than to those of the more recent years (Table I). As in the first period of sampling in 1982, the ratio was of the order of $44: 38: 18$ for $\left(\mathrm{Na}^{+}+\mathrm{K}^{+}\right)$: $\mathrm{Ca}^{++}: \mathrm{Mg}^{++}$.

\section{ISOTOPIC COMPOSITION OF GLACIER-RIVER WATER}

The water leaving Austre Okstindbreen at any time is a mixture of components, each of which has its own isotopic signature. Whilst mixing of waters within glacierdrainage systems tends to cause homogenization (Ambach and others, 1976) it does not entirely eliminate all systematic variations of isotopic composition. Early in the ablation season in periods of fine weather a daily isotope cycle lags about $6 \mathrm{~h}$ behind that of air temperature, but the lag tends to decrease as the summer advances (Theakstone, 1986). The diurnal variations are superimposed on longer-term trends, which are apparent when the extreme, median, and quartile $\delta^{18} \mathrm{O}$ values of samples collected over periods of $3 \mathrm{~d}$ are plotted (Fig. 3). The trends shed some light on drainage conditions at the glacier; between 9 and 14 July 1987, glacier-river discharge declined as the previous winter's snow cover in the lower part of the catchment melted away; a week-long period of generally increasing discharge, during which the transient equilibrium line moved up-glacier, was followed by a general decline, associated with a much-increased cloud cover, which was mirrored by the $\delta^{18} \mathrm{O}$ values of the river-water samples (Theakstone, 1988). Between-year differences of these within-season trends probably reflects changing spatial patterns of drainage.

Inputs of rainwater, the displacement of water stored within and beneath the glacier, and outbursts of the glacier-dammed lake (Knudsen and Theakstone, 1988) cause departures from the systematic seasonal and daily pattern of $\delta^{18} \mathrm{O}$ values in samples collected from the glacier river. In 1982,1985 , and 1986, Kalvtjørna drained before the programme of sampling river water had begun. In 1981 and 1983, the lake remained full throughout the field season, but in 1984 it drained on 24 July, sampling having begun 

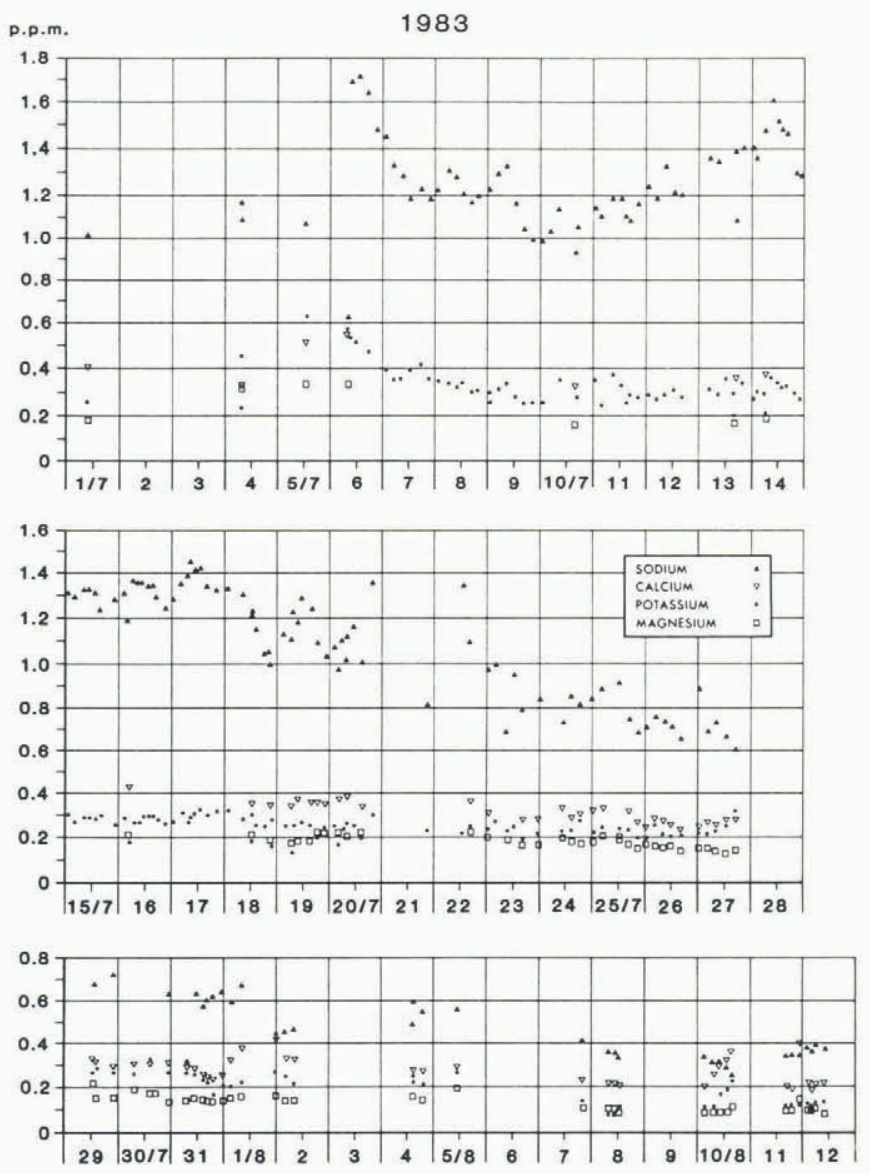

Fig. 2. Cation concentrations in the main river issuing from Austre Okstindbreen, 1983 summer season.

$11 \mathrm{~d}$ earlier. In 1987, the event occurred on 16 July, a week after sampling of glacier-river water had started, but the lake basin did not empty completely.

The range of $\delta^{18} \mathrm{O}$ values for samples collected from the northern glacier river in 1981 differed strikingly from those collected in other years (Table II); the source, or sources, of the water was probably not the same as that which generally dominates flow in the principal glacier river. Samples collected from the northern river in 1985 until 22 July had higher $\delta^{18} \mathrm{O}$ values than had samples taken from the southern river, which were similar to those obtained in previous years from the main outflow (Fig. 4). After 22 July $1985, \delta^{18} \mathrm{O}$ values of samples from the northern river were low (Table II).

\section{DISCUSSION}

Some of the water formed by ablation-area melting in summer passes quickly through Austre Okstindbreen in conduits, but some is delayed in transit. Accumulation-area melting contributes to the base-flow component of discharge. The hydrological systems within the glacier are variable; early in the summer, several systems of inter-connected moulins, conduits, and cavities may exist, but in the course of the ablation season, as internal connections develop, glacier drainage is likely to be accommodated by fewer, more extensive systems (Theakstone, 1978). Several outbursts from Kalvtjørna have been preceded by disruption of these drainage systems. Although the river which discharged from the glacier to Kjennsvatnet for much of this century ceased to flow in 1980 , it was re-activated during the 1984 outburst of Kalvtjørna, when water under pressure burst through the glacier surface. In 1986 and 1987, the lake basin, which had emptied during the previous summer, did not refill until the following winter's snow cover melted in May-June. Clearly, the channel(s) through which water had escaped from the basin did not close completely before the end of the ablation season, although the channel(s) which linked the

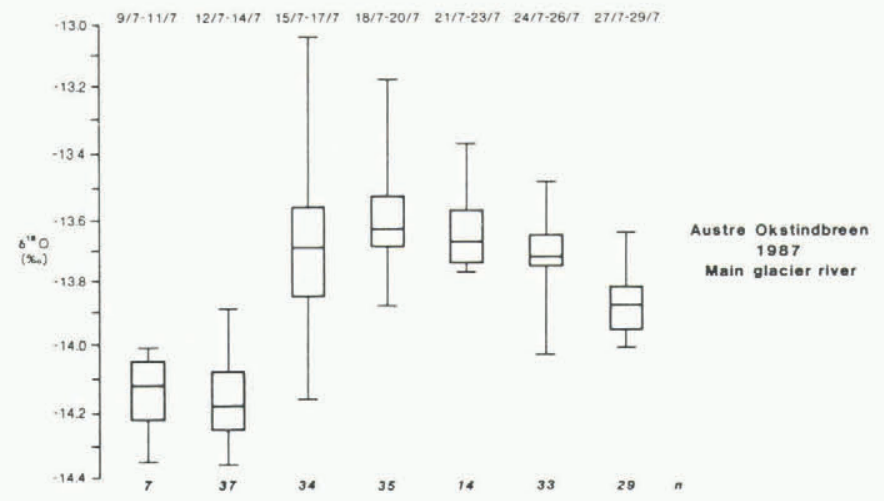

Fig. 3. Extreme, median, and quartile $\delta^{18} \mathrm{O}$ values in samples of glacier-river water collected during successive $3 \mathrm{~d}$ periods in July 1987. (Sampling periods indicated at top.) Number of samples $(n)$ represented by summary statistics is indicated at bottom.

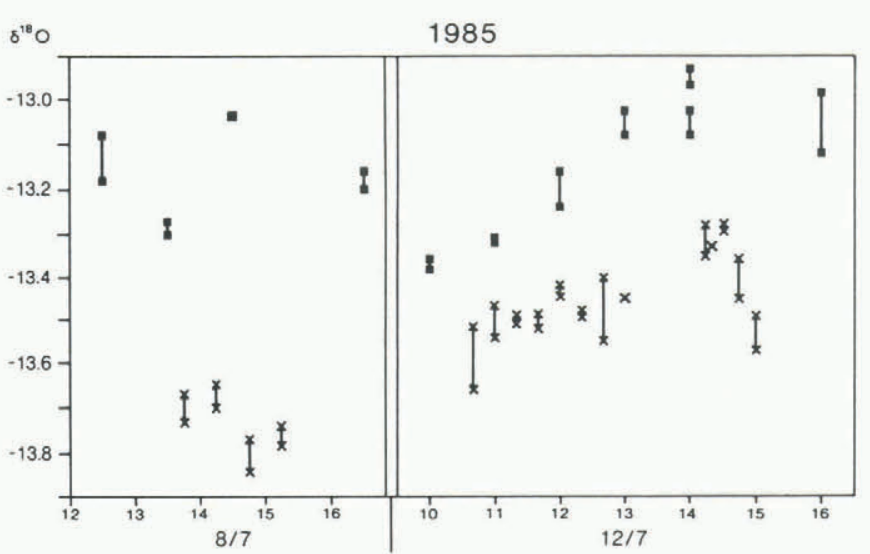

Fig. 4. $\delta^{18} \mathrm{O}$ values of samples collected on 8 and 12 July from the two rivers which issued from Austre Okstindbreen in the first part of the 1985 summer showed significant differences. Each sample was analysed twice, and both sets of ${ }^{18} \mathrm{O}$ values are plotted. Northern river samples are represented by squares, and southern river samples by crosses.

basin and the main glacier-river system closed down during the winter.

In the 12 year study period only once, in 1985, did the point of exit of the principal river from the glacier suffer a major change once it had become established at the beginning of the summer. Like the outburst of the glacier-dammed lake in 1982, the event occurred during a storm, at a time of heavy precipitation. As well as having a direct effect on its drainage systems, above-normal inputs of water to the glacier, whether of climatic origin or resulting from glacier-dammed lake outbursts, may change the geometry and volume of storage zones at the glacier bed. This will have subsequent effects on solute acquisition by water stored there, as is shown by the water-quality data for 1985 and 1986 when Kalvtjørna drained through the glacier shortly before sampling began.

The differences in general water chemistry exhibited by the rivers sampled since 1981 suggest that the nature of solute acquisition by water passing through and beneath Austre Okstindbreen varies from one year to another. Similarities between years may indicate that in summers with similar patterns of water-chemistry variations the routes followed by the water at the glacier bed may have been through similar areas. Thus, solute acquisition by the main (northern) river in its subglacial course in 1983 and 1984 apparently was similar to that of the main (southern) river in 1981 and to that of the northern river which discharged into the $760 \mathrm{~m}$ pond in 1982. In general, solute concentrations recorded in these years were low and the dominant cation was $\mathrm{Na}^{++}$. The solute content acquired by the main (northern) river in 1985 and 1986 differed from that of the previous years; the major change in the 
TABLE II. SUMMARY STATISTICS OF ISOTOPIC COMPOSITION $\left(8^{18} \mathrm{O}\right.$ VALUES, $\left.q_{C}\right)$ OF WATER SAMPLES FROM AUSTRE OKSTINDBREEN. SAMPLES 1985S COLLECTED FROM SOUTHERN RIVER; ALL OTHERS COLLECTED FROM NORTHERN RIVER. (IN ADDITION TO BEING GROUPED, SAMPLES COLLECTED BEFORE AND AFTER $18.00 \mathrm{~h}$ ON 22 JULY 1985 ARE LISTED SEPARATELY.) SAMPLING INTERVAL IN HOURS. SAMPLING WAS INTERRUPTED IN ALL PERIODS

\begin{tabular}{|c|c|c|c|c|c|c|c|c|c|c|c|}
\hline & 1980 & 1981 & 1982 & 1983 & 1984 & 1985 & 1986 & 1987 & $1985 \mathrm{~S}$ & $1985 \mathrm{~A}$ & 1985B \\
\hline Maximum & -12.37 & -10.99 & -12.54 & -11.83 & -12.41 & -12.64 & -12.02 & -13.00 & -13.28 & -12.64 & -13.32 \\
\hline Upper quartile & -12.82 & -11.56 & -12.85 & -12.74 & -13.13 & -12.41 & -12.64 & -13.02 & -13.00 & -13.02 & -13.59 \\
\hline Median & -12.97 & -11.68 & -13.02 & -13.02 & -13.34 & -13.37 & -12.72 & -13.75 & -13.49 & -13.19 & -13.70 \\
\hline Lower quartile & -13.19 & -11.83 & -13.14 & -13.39 & -13.45 & -13.62 & -12.87 & -13.98 & -13.49 & -13.41 & -13.80 \\
\hline Minimum & -13.64 & -12.11 & -13.39 & -13.86 & -13.73 & -14.10 & -13.35 & -14.36 & -13.84 & -13.91 & -14.10 \\
\hline$N$ & 16 & 20 & 60 & 240 & 183 & 336 & 262 & 188 & 17 & 238 & 98 \\
\hline Sampling period & $10 / 7-24 / 8$ & $13 / 8-4 / 8$ & $15 / 7-19 / 8$ & $1 / 7-12 / 8$ & $13 / 7-2 / 8$ & $6 / 7-27 / 7$ & $11 / 7-29 / 7$ & $9 / 7-29 / 7$ & $7 / 7-12 / 7$ & $6 / 7-22 / 7$ & $22 / 7-27 / 7$ \\
\hline Sampling interval & - & - & 6 & 4 & 2 & 1 & 2 & 2 & - & 1 & 1 \\
\hline
\end{tabular}

hydrological system in July 1985 was not reflected in the proportions of the cations present, although the concentrations changed as a result of dilution. In 1987, the general water chemistry was different from that indicated by samples in any previous period, except for the northern river as it entered the $740 \mathrm{~m}$ lake in the first part of the 1982 summer.

The isotopic composition of the water discharging from Austre Okstindbreen reflects the differing proportions of various contributing sources, some of which are much more depleted in ${ }^{18} \mathrm{O}$ than are others (Theakstone, 1988). Because the isotopic signatures of water formed from melting glacier ice and that formed from melting snow are not significantly different, the general range of oxygen-isotope values for a particular summer does not indicate whether, in that year, the role of melt water from the previous winter's snow cover is more, or less, substantial than is that of glacier ice melt water. However, as $\delta^{18} \mathrm{O}$ values of bulk glacier-river water are much lower than those for both old snow and glacier ice (Theakstone, 1988), the general level of a summer's values does indicate the relative contribution of the base-flow component of discharge, which may be sustained by accumulation-area sources or by water released from storage in or beneath the glacier. The data obtained from the northern river in 1981 indicate clearly that this ${ }^{18} \mathrm{O}$-depleted component was not significant; in that summer the northern river was sustained largely by surface melting in the ablation area. In 1986, the isotopically light component was less significant than in the following year, when $\delta^{18} \mathrm{O}$ values were lower.

\section{CONCLUSIONS}

Solute acquisition by the rivers discharging from Austre Okstindbreen varies as the organization of the drainage systems varies. The time of occurrence of outbursts from the glacier-dammed Kalvtjørna lake may be an important control for that organization. Both the changing efficiency of glacier drainage and spatial and temporal differences of snow and ice melting between summers are reflected in changes of the isotopic composition of glacier river water (Fig. 3). General between-year contrasts of water quality (represented by $\delta^{18} \mathrm{O}$ values and cationic composition) are not masked by the short-term trends and variations which are not examined in this paper. Year-to-year changes are marked, indicating that glacier-drainage conditions during a particular summer may not represent a more general situation. The temporal changes in the hydrological systems of the glacier reflected by the water-quality data include changes in the basal component. This has significant implications in relation to the utilization of subglacial water intakes for hydro-electric power stations.

\section{ACKNOWLEDGEMENTS}

Since 1980, about 1500 samples from Austre Okstindbreen have been analysed at the Copenhagen
University Geophysical Isotope Laboratory, thanks to the willing co-operation of Professor W. Dansgaard and N. Gundestrup. Field investigations at the glacier have benefited greatly from the participation of Professor J.T. Møller, whose advice and company have done much to ensure the success of the Okstindan Glacier Project. We are grateful to the several postgraduate students from Manchester and Aarhus Universities who have assisted with data collection, in particular J-O. Andreasen, O. Bendixen, C. Durbin, M. Jeffries, P. Reimann, and L. Svendssen. We thank N. Scarle for cartographic work. Financial support from the U.K. Natural Environment Research Council, the Royal Society, the British Council, the University of Manchester, and Statens Naturvidekskabelige Forskningsråd is acknowledged with gratitude.

\section{REFERENCES}

Ambach, W., and 6 others. 1976. Deuterium, tritium and gross-beta-activity investigations on Alpine glaciers (Ötztal Alps). J. Glaciol., 17(77), 383-400.

Ballantyne, C.K. and S.B. McCann. 1980. Short-lived damming of a high-Arctic ice-marginal stream, Ellesmere Island, N.W.T., Canada. J. Glaciol., 25(93), 487-491.

Burkimsher, M. 1983. Short-term irregularities of discharge of glacial melt-water streams. J. Glaciol., 29(101), 198-199.

Clarke, G.K.C. 1987. A short history of scientific investigations on glaciers. J. Glaciol., Special Issue, 4-24.

Hoel, A. 1910. Okstinderne. Fjeldgrunden og bræerne. Nor. Geol. Unders. Aarbok, 57(II).

Knighton, A.D. and W.H. Theakstone. 1978. Throughflow water velocities in Austre Okstindbreen, Norway. $J$. Glaciol., 20(84), 598-599.

Knudsen, N.T. 1978. Drainage of an ice-dammed lake, Okstindan, Nordland, Norway. Nor. Geogr. Tidsskr., 32(2), 55-61.

Knudsen, N.T. and W.H. Theakstone. 1988. Drainage of the Austre Okstindbreen ice-dammed lake, Okstindan, Norway. J. Glaciol., 34(116), 87-94.

Raiswell, R. 1984. Chemical models of solute acquisition in glacial melt waters. J. Glaciol., 30(104), 49-57.

Reimann, P. Unpublished. Glacialt smeltevands kemiske karakteristiker ved Austre Okstindbre i Norge. Aarhus Universitet. Geologisk Institut. Specialrapport, 1987.

Theakstone, W.H. 1978. The 1977 drainage of the Austre Okstindbreen ice-dammed lake, its cause and consequences. Nor. Geogr. Tidsskr., 32(4), 159-171.

Theakstone, W.H. 1986. Water movement through the glacier Austre Okstindbreen: evidence provided by isotopic analysis. Okstindan Glacier Project. Report 86.5.

Theakstone, W.H. 1988. Temporal variations of isotopic composition of glacier-river water during summer: observations at Austre Okstindbreen, Okstindan, Norway. J. Glaciol., 34(118), 309-317.

Theakstone, W.H. and N.T. Knudsen. 1981. Dye tracer tests of water movement at the glacier Austre Okstindbreen, Norway. Nor. Geogr. Tidsskr., 35(1), 21-28. 